\title{
INTELLIGENS MEGOLDÁSOK AZ EGYSÉGES VONATBEFOLYÁSOLÁS TERÜLETÉN
}

\author{
Erdei László \\ PhD hallgató, Miskolci Egyetem, Logisztikai Intézet \\ 3515 Miskolc, Miskolc-Egyetemváros, e-mail: erdei.laszlo1995@gmail.com
}

\section{Bányai Tamás}

egyetemi docens, Miskolci Egyetem, Logisztikai Intézet

3515 Miskolc, Miskolc-Egyetemváros, e-mail: alttamas@uni-miskolc.hu

\begin{abstract}
Absztrakt
Számos logisztikai folyamat van, amelyek lefolyásánál és szervezésénél döntö fontosságú az alkalmazott szállitási ágazat. Különbözö szállitási ágazatok között vannak gyorsabb és rugalmasabb lehetöségek, mint a vasút. Viszont az egységes modern vonatbefolyásolási rendszerek alkalmazásával növelhetö a versenyhelyzet a kötöttpályás szállitási szektorban. A vonatbefolyásolás során alkalmazott IT rendszerek megbizhatósága és rendelkezésre állása nagymértékben befolyásolja a szolgáltatás minöségét. Jelen munka egy már publikált intelligens vonatbefolyásolási szint adatainak kezelését mutatja be elméleti és gyakorlati megközelitésböl.
\end{abstract}

Kulcsszavak: IT rendszer, ETCS, vonatbefolyásolás, biztonságos fékút, GSM-R

\section{Abstract}

The different types of transport sectors have a great impact on logistics processes. Among different transport sectors there are many options which are faster and more flexible than rail transportation. On the other hand, the modern train control systems can increase their availability and reliability with IT devices. This work presents a theoretical and practical approach to analysing of data from intelligent train control system level.

Keywords: IT system, ETCS, train control, safety breaking distance, GSM-R

\section{Bevezetés}

A vonatbefolyásolás témában az egyik legjelentősebb hazai irodalomnak számít az [1] forrás, amely a MÁV Baross Gábor Oktatási Központ közremüködésével készült el. Ez az anyag összefoglalásként és oktatási segédletként támogatja a hazai fejlesztéseket és kutatásokat. Ezen kívül [2] müszaki oldalról mutatja be az ETCS vonatbefolyásoló rendszert. Mindkét anyagban bemutatásra kerülnek a különböző ETCS szintek, amelyek a vasúti pályaszakaszokon betöltött funkciók és a szolgáltatott információk szerint különülnek el egymástól. Előnyök és hátrányok megnevezésével levezetve majd azok kiaknázásával kerül bemutatásra egy magasabb vonatbefolyásolási szint, amely leküzdi az előző szintek hátrányait. Ezen tervezési koncepció mentén lettek a tervezési munkák elvégezve a vonatbefolyásolás területén. A kiépítettség, a kommunikáció, az információ és azok továbbítása területén szükségszerü alkalmazni modern és digitalizációs megoldásokat. A vonatbefolyásoló rendszerek pályamenti rendszerelemeinek külső veszélyeknek való kitettsége és meghibásodási gyakorisága egy javításra szoruló gyengepont. Ezen kívül a folyamatos valós idejü adatfeldolgozás 
területén is van számos fejlesztési lehetőség. Továbbá a helyzetmeghatározás, az éberségfigyelő rendszer és további biztonsági paraméterek kezelésének tekintetében is számos fejlesztési lehetőség feltérképezhetö.

Az ETCS egyik célja az európai egységesítés, vagyis az EU tagállamok akadálynélküli átjárhatósága. Ennek vonatkozásában mindenképpen az ETCS fő célkitüzéseire szükséges alapozni a fejlesztést. Ezáltal felhasználható [3] forrásanyag is. Ebben egy ETCS Level 4 vonatbefolyásolási rendszer elméleti modellje került kidolgozásra. A modell az ETCS Level 2 szintjét veszi alapul, viszont letisztultabb és modernebb módon vezeti be a helyzetmeghatározást, a vezeték nélküli kommunikációt, a fékútszámítást és az éberségfigyelő berendezéseket a rendszerszemléletbe. Ezek a főbb alrendszerei az ETCS Level 4-nek, amelyeket tovább szükséges elemezni az irodalomban.

A vonatbefolyásolásnak, így az ETCS-nek is az egyik alap kiszolgálója egy hatékony és

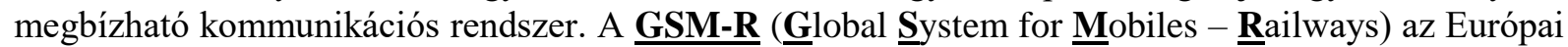
Parlament irányelvei által szabványosított vasúti kommunikáció rendszer. A GSM-R vezeték nélküli kommunikációs rendszer, amely megvalósítja az irányítók, vonatok, üzemeltető személyzet közötti beszédátvitelt és hordozószolgálatot nyújt a vonatbefolyásoló rendszerek adatátvitelének számára. Hatékony és megbízható kommunikációt képes biztosítani az ETCS Level 4 vonatbefolyásolási szint megnövekedett mennyiségü információi számára is.

A vasúti fékezések vizsgálata lassan 200 éves múltra vezethető vissza. Amint megoldottá vált a szerelvények egyre nagyobb sebességü továbbítása, így nőtt annak a szükségessége, hogy minél hatékonyabb és gyorsabb legyen a fékezés. Az idő múlása viszont a régi elveket felülírta, így szükséges újabb szabályokat kidolgozni és felhasználni a digitalizáció által nyújtott lehetőségek kihasználása érdekében a fékezési rendszerek tervezéskor. A vasúti közlekedés egyik fontos vizsgálati aspektusa a biztonságos fékutak elemzése. Az ETCS Level 4 modelljében definiálásra került egy dinamikus fékútszámító alrendszer. Ez képes lehet együttmüködni már meglévő, vagy újabb fékútszámító rendszerekkel. Lengyel György vasútgépészetben megjelent - Fékszámitás és vonat menetdinamikai ellenörzö program címü cikke jó elöirányzata a közlekedési rendszerekben fellépö digitalizációnak. Ebből eredendően a fékútszámítást támogathatja számos IoT megoldás és mesterséges intelligencia. A cikkben bemutatott programmal lehetséges egyedi és vonatba sorolt jármüvek fékezési, gyorsulási úthosszainak ellenőrzése, féküzemi, haladási és gyorsulási menetdinamikai jellemzőinek (pl. ütközőre, vonóelemekre ható erők) meghatározása. Az egyedi adatok háttértáblából kerülnek beolvasásra a külső tényezők pedig kézzel beállíthatók. A leírt vizsgálatban a MÁV-Start egyik Bombardier TRAXX típusú mozdonyára lett tesztelve a fékrendszer és a fékutak. A fékezési rendszer paramétereiböl történő számítás nincs levezetve, csupán eredményjellegü adatok lettek publikálva. Mivel a fékrendszerek egyediek, így nyilvánvalóan nem képezheti ez a rendszer a szakmai beszámolóm számításainak alapját. Ettől függetlenül a vizsgálati eredményekből le lehet vonni számos következtetést. A fékútszámitó és vonat menetdinamikai ellenörzö program integrálva és fejlesztve hatékony alapja tudna lenni az ETCS Level 4 vonatbefolyásolási szint fékútszámító alrendszerének (1. ábra).

Az éberségfigyelés fontos a vasúti közlekedés során. A hazánkban használatos ilyen jellegü rendszerek elavultak és a megnőtt teljesítőképességnek már nem tudnak megfelelően eleget tenni. Itthon a mozdonyvezetőknek még mindig egy lábbal folyamatosan nyomva tartott pedál felengedésével kell nyugtázni az elöre meghatározott, de fix idő- vagy távolságközönként érkező éberségi jelzéseket. 
Nemzetközi viszonylatban (EU, Távol-Kelet stb.) különböző vasúttársaságoknál már változatosabb az éberségfigyelés, mivel nem csak pedállal lehetséges a nyugtázás, hanem például müszerfalon lévő nyomógomb segítségével is. Viszont az elv nem változott, mivel fix időközönként érkeznek a jelzések és a nyugtázás mulasztása esetén automatikusan megáll a vonat. A $200 \mathrm{~km} / \mathrm{h}$ sebesség alatti vasúti üzem esetén nincs szükség magas szintủ éberségfigyelésre, ahol például mesterséges intelligencia alapú gépi látással vizsgálják a mozdonyvezető viselkedését. Viszont a biztonságos vasúti közlekedés számára az is hatékony fejlesztési törekvés, ha nem kiszámítható időközönként érkeznek az éberségi jelzések, illetve szabályszerủen változtatható a nyugtázási mód. Továbbá az éberségfigyelő rendszernek a hatékony üzemelés szempontjából együtt kell tudnia müködni a vonatbefolyásoló rendszerrel.

\begin{tabular}{|c|c|c|c|}
\hline \multicolumn{4}{|l|}{ Fék } \\
\hline Villamos fék & & & \\
\hline Villamos fék van-e & \multirow{2}{*}{ loen } & 1 & 1 \\
\hline Vontatómotor hatásfok & & 0,98 & 0,98 \\
\hline Transzformátor hatásfok & 0,98 & 0,98 & 0,98 \\
\hline Hajtáslánc hatásfoka & 0,98 & 0,98 & 0,98 \\
\hline $\begin{array}{l}\text { Elméleti visszatáplált } \\
\text { teljesítmény }\end{array}$ & 192 & 5271 & 5271 \\
\hline \multicolumn{4}{|l|}{ Pneumatikus fék } \\
\hline Van-e pneumatikus fék? & nem $\longrightarrow$ & 0 & 1 \\
\hline Féktipus & Tárcsa - & 2 & 2 \\
\hline Van-e fékhiszterézis? i/n & nem - & 0 & 0 \\
\hline Nagynyomás bar & 8 & 0 & 0 \\
\hline Átkapcsolási sebesség - felsô & 80 & 0 & 0 \\
\hline Kisnyomás bar & 3,8 & 0 & 0 \\
\hline $\begin{array}{l}\text { Átkapcsolási sebesség - alsó } \\
\mathrm{km} / \mathrm{h}\end{array}$ & 55 & 0 & 0 \\
\hline Fékhengerek száma & 8 & 8 & 8 \\
\hline Fékhenger átmérôje " & 10 & 8 & 8 \\
\hline Fékhenger ellenerō $\mathrm{N}$ & 1500 & 1500 & 1500 \\
\hline Fékrendszer áttétele: & 8,51 & 8,51 & 8,51 \\
\hline Fékváltó álása & $\mathrm{P}-\mathbf{T}$ & G & G \\
\hline Rudazati hatásfok: & 0,8 & 0 & 0 \\
\hline Féktárcsa max. átméröje mm & 305 & 920 & 920 \\
\hline Féktárcsák száma: & 8 & 8 & 8 \\
\hline
\end{tabular}

1. ábra. Fékrendszer paramétereinek beállitó panelje

\section{Gyakorlati megvalósítás}

Az ETCS Level 4 szintű vonatbefolyásolás egyik újszerü alapja a GPS általi nyomonkövetés. A mozdonyokban elhelyezett GPS jeladó biztosítja a helymeghatározást. Az így definiált forrás egy GPS koordinátát és egy hozzárendelt időpillanatot szolgáltat. Ennek az adatszolgáltatásnak a sürüsége beállítható, viszont a másodpercenként történő feldolgozás még egy könnyen kivitelezhető és egyszerü konstrukció. Ebből a két adatból számos messzemenő következtetést tudunk megállapítani, illetve fontos információkat szolgáltatni különböző ETCS Level 4 alrendszerek müködtetéséhez.

\section{Alapszámítások}

A vasúti üzem lassan 200 éves múltjára visszatekintve belátható, hogy a vasúti közlekedés népszerüsége egyenes arányosságot mutatott a szerelvények menetsebességének növekedésével. Ahogyan a vonatok sebessége növekedett, úgy egyre hatékonyabb fékezési rendszereket és egyéb biztonsági megoldásokat kellett alkalmazni, bevezetni és szabványosítani. Így a sebesség 
függvényében kerül definiálásra számos biztonsági faktor; elsőnek a rendelkezésre álló adatokból való sebességszámítás megoldása szükséges, mint alapszámítási feladat (1. táblázat).

1. táblázat. Kiinduló adatok

\begin{tabular}{|c|c|}
\hline Koordináta $\left[\mathbf{X} \mathbf{x x}^{\circ} \mathbf{x x}, \mathbf{x x x}\right]$ & Pontos idő [hh:mm:ss] \\
\hline $\mathrm{N} 46^{\circ} 40.187^{\prime} \mathrm{E} 21^{\circ} 04.871^{\prime}$ & $14: 19: 14$ \\
\hline $\mathrm{N} 46^{\circ} 40.197^{\prime} \mathrm{E} 21^{\circ} 04.869^{\prime}$ & $14: 19: 39$ \\
\hline
\end{tabular}

Ebben az esetben a sebességet nem feltételezhetjük minden esetben egyenesvonalú egyenletes mozgásnak. Így az általános képletből származtatható a két pont közötti sebesség:

$$
v=\frac{s}{t} \quad \rightarrow \quad v_{n+1}=\frac{\Delta s}{\Delta t}
$$

ahol:

$$
\begin{aligned}
& v_{n+1}-\text { sebesség két koordináta között }\left[\frac{\mathrm{m}}{\mathrm{s}} ; \frac{\mathrm{km}}{\mathrm{h}}\right] \\
& \Delta s-\text { két koordináta közötti távolság }[\mathrm{m}] \\
& \Delta t-\text { két koordináta feljegyzése között eltelt idő }[\mathrm{sec}]
\end{aligned}
$$

Észrevehető, hogy a kiszámított sebesség mindig csak közelít az aktuális pillanatnyi sebességhez. De a GPS track pontjainak 1 másodpercenkénti sürüsége minimalizálja a pillanatnyi és a számított sebességi közötti differenciát. A $\Delta s$ komponens kiszámítása már nem ilyen egyszerü. A GPS koordináták, mint a Föld globális helymeghatározására szolgáló paraméterek. Ezért olyan összefüggéssel kell számolni, amely figyelembe veszi a Föld görbületét is. Erre jó összefüggés a Haversine formula:

$$
\begin{gathered}
\Delta s=\left(\cos ^{-1}\left(\sin \left(l a t_{n+1}\right) \cdot \sin \left(l a t_{n}\right)+\cos \left(l a t_{n+1}\right) \cdot \cos \left(l a t_{n}\right) \cdot \cos \left(\operatorname{lon}_{n+1}-\operatorname{lon}_{n}\right)\right)\right) \\
\cdot E R
\end{gathered}
$$

ahol:

$$
\begin{aligned}
& \text { lat }_{n}, \text { lat }_{n+1}-\text { szélességi érték az } n \text { és }(n+1) \text { pontban }[\mathrm{rad}] \\
& \operatorname{lon}_{n}, \operatorname{lon}_{n+1}-\text { hosszúsági értek az } n \text { és }(n+1) \text { pontban }[\mathrm{rad}] \\
& E R \text { - a Föld sugara, amely megközelítöleg } 6371 \cdot 10^{3}[\mathrm{~m}]
\end{aligned}
$$

Mivel a Haversine összefüggés a szélességi és hosszúsági értékeket radiánban számolja, ezért ha nem radián az adat bemeneti dimenziója, akkor extra lépésként át kell váltani a koordinátákat a megfelelő formátumba.

$$
\alpha[\mathrm{rad}]=\frac{\alpha\left[^{\circ}\right]}{180 \pi}
$$


Az utolsó lépésként pedig a feljegyzett koordináták dedikált idejeinek különbségeit kell meghatározni:

$$
\Delta t=t_{n+1}-t_{n}[\mathrm{sec}]
$$

2. táblázat. Az képletekbe történö behelyettesités után

\begin{tabular}{|c|c|c|c|c|}
\hline 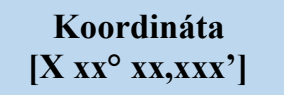 & $\begin{array}{c}\text { Szakasz táv } \\
{[\mathrm{m}]}\end{array}$ & $\begin{array}{l}\text { Pontos idő } \\
\text { [hh:mm:ss] }\end{array}$ & $\begin{array}{l}\text { Szakasz idő } \\
\text { [hh:mm:ss] }\end{array}$ & $\begin{array}{c}\text { Sebesség } \\
{[\mathrm{km} / \mathrm{h}]}\end{array}$ \\
\hline $\begin{array}{c}\mathrm{N} 46^{\circ} 40.187^{\prime}, \mathrm{E} 21^{\circ} \\
04.871^{\prime}\end{array}$ & - & $14: 19: 14$ & - & - \\
\hline $\begin{array}{c}\mathrm{N}^{\prime} 6^{\circ} 40.197^{\prime}, \mathrm{E} 21^{\circ} \\
04.869^{\prime}\end{array}$ & 18,7 & $14: 19: 39$ & 00:00:25 & 3 \\
\hline
\end{tabular}

Ezek az alapszámítások egy része triviális, logikusan levezethető (2. táblázat). A Haversine algoritmus talán a kivétel ezek közül, de ezzel a metódussal könnyen lehet vele távolságot, majd két pont között átlagsebességet számolni. A rendszer által számított adatok rögzítésre kerülnek és meghatározott idejü tárolása kötelező a biztonsági elöírások szerint. Ezen felül további elemzések, statisztikák készíthetők ezekből.

\section{Fékút számítása}

Irodalmi áttekintések során sikerült arra a megállapításra jutni, hogy a vasúti üzem fékútszámításai nem vezethetők le és definiálhatók egzakt módon. Így jelen kutatásban alkalmazott fékezés alapját egyszerü fizikai összefüggések, illetve tapasztalati mérések és publikált vizsgálatok eredményei biztosítják. Ebben a témában hazai és egyéb európai fékezésekkel kapcsolatos kutatásokat, hatásvizsgálatokat tekintettünk át.

A hazai irodalom definiál több fékutat is. A tényleges fékút az a távolság, amelyet a vonat befut a fékezés megkezdésétől a megállásig az adott pályán. Az általános fékút pedig az a távolság, amelyen belül valamennyi vonat, a fékezés megkezdésétől gyorsfékezéssel megállítható, feltételezve a legkedvezőtlenebb külső körülményeket a fékezés folyamán.

A két fékút ismertetése után az alábbi reláció állapítható meg:

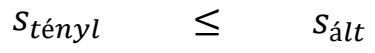

A tényleges fékút egy utólagos távolság, amelyet vészfékezés következtében a pálya mentén befutott távolságot adja meg. A tényleges fékutat ritkán lehet kielégítő pontossággal meghatározni előre, de a ténylegeshez egy jól közelítő értéket viszont igen. Az általános fékút pedig egy biztonsági tényezőkkel számított távolság.

Ahogyan a vonatbefolyásoló rendszerek többségében, így az ETCS Level 4 esetében is szükséges egy fékút mérö/számító program. A fékutak közelítő pontosságú meghatározása biztonsági szintü feladatot képez. További egyedi cél, hogy fékútvizsgálatot tudjon biztosítani az alrendszer.

Az ETCS Level 4 vonatbefolyásolási szintnek a fékútszámító alrendszerében egy úgynevezett biztonságos fékút fogalmat vezetünk be. Ez egy olyan alrendszerként müködik, amely az 
alapszámítási adatokból az aktuális sebesség alapján képes a pálya adottságainak megfelelően prognosztizálni a biztonságos fékezési távolságot (2. ábra).

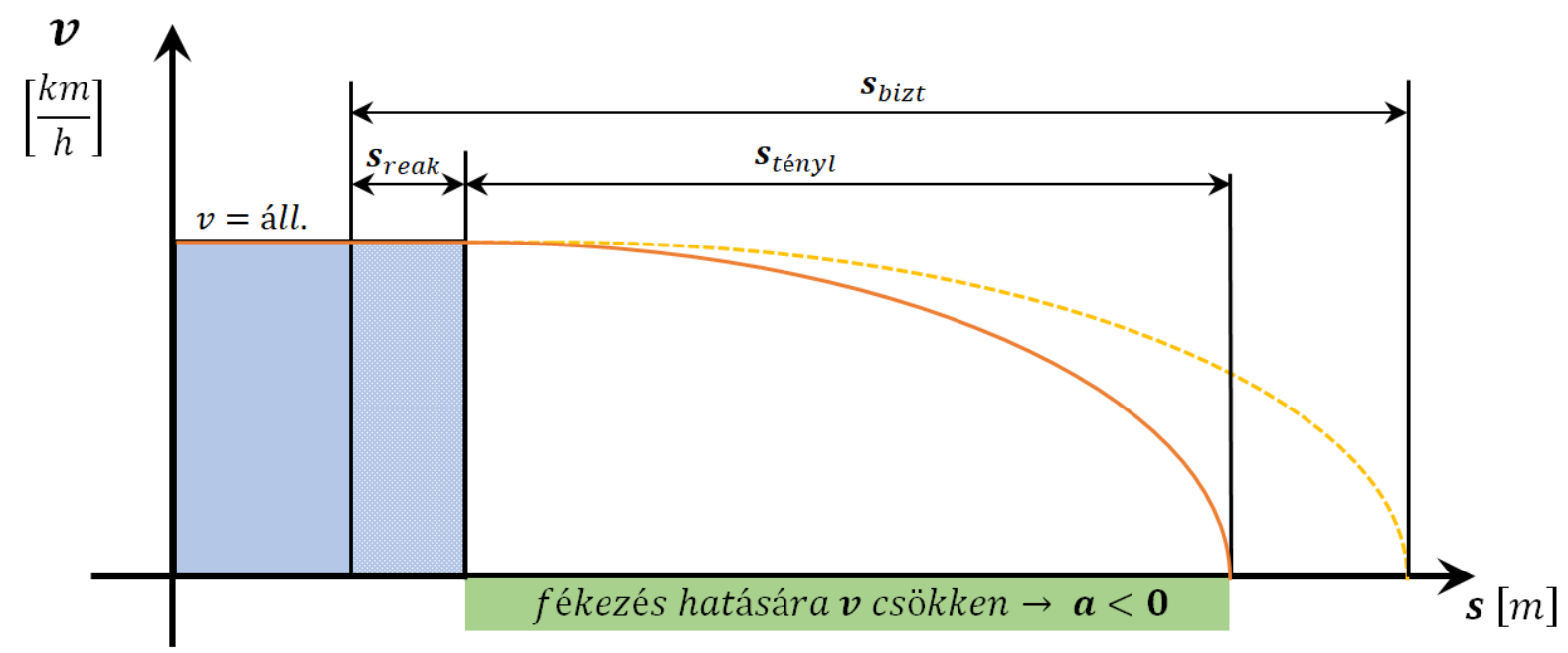

2. ábra. Fékút diagram a sebesség függvényében

A fékútszámító alrendszer fizikai értékek függvényében megfelelő ráhagyással (biztonsági tényezővel) a következő összefüggés alapján számol biztonságos fékutat:

$$
s_{\text {bizt }}=s_{\text {reak }}+\left(1+n_{\text {bizt }} \cdot 100\right) \cdot s_{\text {tényl }}^{\prime}[\mathrm{m}]
$$

ahol

$$
\begin{aligned}
& s_{\text {bizt }}-\text { biztonságos fékút }[\mathrm{m}] \\
& s_{\text {reak }}-\text { reakcióidő alatt megtett út }[\mathrm{m}] \\
& n_{\text {bizt }}-\text { biztonsági ráhagyás }[\%] \\
& s_{\text {bizt }}-\text { biztonságos fékút }[\mathrm{m}]
\end{aligned}
$$

Az előre jelezhető biztonságos fékút, mint látszik több tényezőből áll össze. Először a reakcióidő alatt megtett távolságot érdemes megemlíteni, amelyet az aktuális sebességgel megtesz a vonat az észleléstől, cselekedésen keresztül a fékrendszer müködéséig. A reakcióidő egy átlagos ember esetén 0,3 - 1,7 másodperc között van, tehát átlagosan az emberi reakció ideje körülbelül 1 másodperc. A mérések következtében viszont az észlelés és a fékezés megkezdése elött 1,6 másodperc telt el, ami a cselekvés és a fék működésbe lépésének ideje. A reakció idő alatt megtett út:

$$
s_{\text {reak }}=t_{\text {reak }} \cdot v_{\text {akt }}[\mathrm{m}]
$$

ahol

$$
\begin{aligned}
& t_{\text {reak }}-\text { reakcióidő és fékrendszer üzembelépési ideje } 1,6[\mathrm{sec}] \\
& v_{a k t}-\text { a fékezés kezdő sebessége }\left[\frac{\mathrm{m}}{\mathrm{s}}\right]
\end{aligned}
$$


Biztonságos fékút kiszámításához a prognosztizált tényleges fékutat meg kell szorozni a biztonsági ráhagyást biztosító tényezővel. Mivel a tényleges fékutat elöre csak közelítő pontossággal lehet kiszámolni, így a ráhagyás elengedhetetlen.

A biztonságos fékút legfontosabb tényezőjét a közelítő pontosságú fékutat a következő összefüggés adja meg:

$$
s_{\text {tényl }}^{\prime}=\frac{v_{a k t}^{2}}{2 \cdot\left|a_{a k t}\right|}[m]
$$

ahol:

$$
\begin{aligned}
& v_{a k t}-\text { a szerelvény aktuális sebessége }\left[\frac{\mathrm{m}}{\mathrm{s}}\right] \\
& a_{a k t}-\text { az elérhető aktuálisan legnagyobb lassulás }\left[\frac{\mathrm{m}}{\mathrm{s}^{2}}\right]
\end{aligned}
$$

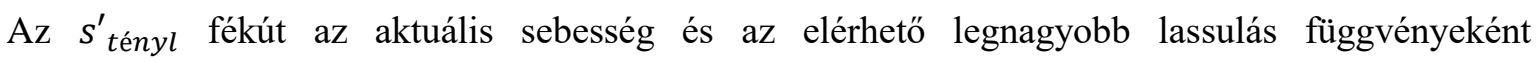
értelmezhető. Az aktuális sebesség adott, amit a rendszer automatikusan szolgáltat, viszont a lassulás mértékét még számos paraméter befolyásolja. Ezek a paraméterek lehetnek statikusak és dinamikusak. Statikus paraméterekhez azok a jellemzők tartoznak, amik egyedi tulajdonságok és állandó jellegüek. A dinamikus paraméterek azok, amelyek térben és időben változók.

A legfontosabb fékutat befolyásoló paraméterek:

- Statikus jellemzők:

$>$ fékezési teljesítmény,

$>$ az alkalmazott fékrendszer,

$>$ fékezett tengelyek száma,

$>$ tömeg,

$>$ a pálya lejtésének vagy emelkedésének a meredeksége stb.

- Dinamikus jellemzők:

$>$ csúszás elleni védelem mértéke,

$>$ a sín aktuális felületi súrlódási együtthatója stb.

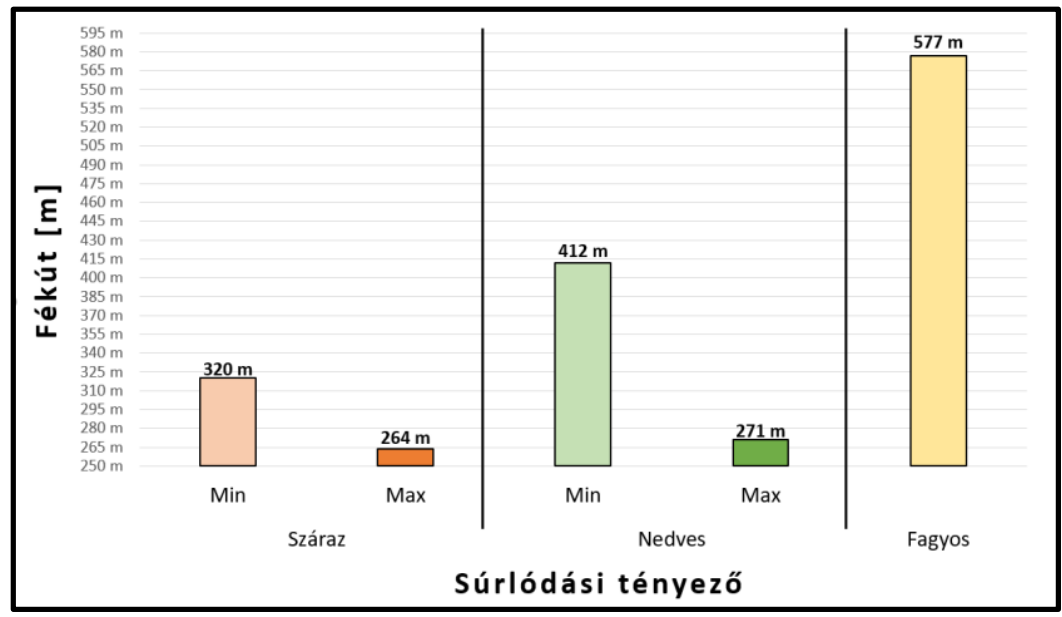

3. ábra. Fékutak különbözö időjárási és súrlódási közegekben 
A statikus fékezési paraméterek mindig egyedi értékekként jelennek meg, mivel egy vasúti szerelvény összeállítása, terhelése nem determinisztikus. A további érdemleges számításokhoz a dinamikus paraméterek vizsgálata a releváns. Az aktuális lassulás átlagértékét utólagos mérések által könnyen meg lehet határozni. Így a [7] szakirodalmi forrásban vázolt mérési eredményeket fogjuk felhasználni, hogy megállapítsuk az átlagos lassulást néhány egyedi esetre vonatkoztatva. Az említett anyagban publikálásra kerültek különböző időjárási körülmények között mért fékutak. Mind maximális és minimális fékezés során fellépő súrlódási paraméterek tekintetében (3. ábra).

A 3. ábrán látható értékek egy mozdony $120 \mathrm{~km} / \mathrm{h}$ sebességről állóhelyzetbe történő vészfékezéséből adódnak. A 2. ábrán látható a teljes fékezés (vészfékezés) folyamata. A különböző közegek és az időjárási viszonyok nagymértékben tudják befolyásolni a fékezési távolságokat, főleg ha a futófelület és a sín között nincs megfelelő mértékủ súrlódási együttható. Fagyos időben, ónos esőben pedig kétszeres is lehet ez a távolság. Az átlagos lassulást így meg lehet határozni a (7) képlet átalakításával:

ahol:

$$
a_{a k t}=\frac{v_{a k t}{ }^{2}}{2 \cdot s_{x}}\left[\frac{m}{s^{2}}\right]
$$

$$
\begin{aligned}
& v_{a k t}-\text { a szerelvény aktuális sebessége }\left[\frac{\mathrm{m}}{\mathrm{s}}\right] \\
& s_{x}-\text { a megadott közeg és mechanikai tulajdonságok alapján mért fékutak }[\mathrm{m}]
\end{aligned}
$$

Továbbá a forrásból származó adatoknak ismerjük két bemeneti értékét, így megtudjuk határozni az adott közegeknek és tulajdonságoknak megfelelően az elérhető átlagos lassulást. Ismert a kezdeti sebesség, illetve, az egyes fékutak.

3. táblázat. Az egyes közegekhez és tulajdonságokhoz tartozó átlagos lassulási értékek

\begin{tabular}{|l|l|c|c|c|}
\hline Időjárás & $\begin{array}{c}\text { Súrlódási } \\
\text { feltételek }\end{array}$ & FÉKÚT & & Lassulás \\
\hline \hline Száraz & Min & $320 \mathrm{~m}$ & $\mathbf{1 , 7 4}$ \\
& Max & $264 \mathrm{~m}$ & $\mathbf{2 , 1 0}$ \\
\hline Nedves & Min & $412 \mathrm{~m}$ & $\mathbf{1 , 3 5}$ \\
& Max & $271 \mathrm{~m}$ & $\mathbf{2 , 0 5}$ \\
\hline Fagyos & & $577 \mathrm{~m}$ & $\mathbf{0 , 9 6}$ \\
\hline
\end{tabular}

Így a 3. táblázatban kiszámított lassulás értékeket abszolútértékben ábrázoljuk, mivel a negatív gyorsulásból származó negatív előjel nem releváns ebben a számításban. Az előbb kiszámított átlagos értékekkel lehet biztonságosan számolni. Így folyamatosan, valós időben képes a rendszer biztonságos fékútszámításra. Hazánkban jelenleg erre nincs példa. A dinamikus definiált külső paraméterek változtatásával pedig tud a rendszer alkalmazkodni a változó feltételekhez. 


\section{Éberségfigyelő rendszer}

A vasúti üzem során számos biztonsági rendszer és szabályzás van. Az éberségfigyelő rendszerek használata a monoton munkavégzésben történő figyelemcsökkenést hivatott meggátolni. Az irodalmi áttekintés minimális betekintést nyújtott az éberségfigyelő rendszerekbe. Hatékonyabb, hogyha egyesítve van a vonatbefolyásolási rendszerrel. Az ETCS Level 4 vonatbefolyásoló rendszer éberségfigyelő alrendszerének az alapszámítási alrendszer szolgáltatja a sebességadatot.

Főbb újdonságok az ETCS Level 4 éberségfigyelő alrendszerében a változó időközönként érkező éberségi jelzések (20-80 másodperc), a kétféle módszer az éberségi jelzések nyugtázása, a szabályszerüen választható kívánt nyugtázási mód, a nyugtázási módváltó és nem utolsósorban a hangos és vizuális éberségi jelzés.

Azáltal, hogy a vonatbefolyásoló rendszer egyesítve van az éberségfigyelö rendszerrel kölcsönösen tudnak adatot szolgáltatni egymásnak. Ilyen információ lehet például az aktuális sebesség, sebességkorlátozások, biztonságos fékút, szerelvények közötti távolság stb. A változó időközönként érkező jelzések indokolt esetben lehetnek sürübbek vagy ritkábbak, de két egyforma időintervallummal semmiképpen nem érkezhet jelzés.

Jelzések közötti idő csökkentése $\rightarrow$ sürübb jelzések:

- ráfutásos balesetek elkerülés érdekében való jelzés a szerelvény elött haladó vonat miatt, ha vészfékezne valami oknál fogva;

- lakott területekhez közeli helyeken;

- szintbeli útátjárón való áthaladáskor;

- közös kommunikációs platformon közölt információ miatt (pl.: vadátjárás vagy egy szakaszon a szél csapkodja a felsővezetékeket stb.);

- vonatbefolyásolás nélküli pályán való közlekedés esetén;

- olyan vasútállomáson áthaladva, ahol utasok várakoznak szerelvény mögött közlekedö vonatra,

- sebességkorlátozás-csökkentés előtt, melynek okai lehetnek (pl.: vágányváltás, hegyi terepen, ahol kis ívsugarú kanyarok következnek, a pálya állapota miatt, pályán való munkavégzés esetén, szélsőséges időjárás (pl.: ónos eső)).

Jelzések közötti idő növelése $\rightarrow$ ritkább jelzések:

- egyenes nyílt pályán, ahol nincsenek kis ívsugarú kanyarok, ezáltal sebességkorlátozás se;

- hosszú hidakon (pl.: hosszú mocsaras területek felett átívelő hidakon);

- olyan szakaszokon, amely mentén biztonsági kerítés húzódik a vasúti pálya mentén (a sínekre való bejutás elkerülés érdekében);

- városi szakaszokon, ahol zajvédő fal választja el a veszélyt okozó tényezőket.

Az alábbi folyamatábra írja le az elindulás és a megállás rendszerhatárok közötti éberségfigyelö logikai müködését (4. ábra). A rendszer egyedi számlálója akkor indul el, amikor a mozdony sebessége eléri a $15 \frac{\mathrm{km}}{\mathrm{h}}$ sebességet. Ez a tulajdonság megegyezik a MÁV-Start kötelékeiben lévő mozdonyok éberségfigyelő berendezésével (EÉVB).

A nyugtázási módok között egy kétállású kapcsolóval lehet váltani. Az a nyugtázási mód lesz az első ciklusban, ahol a számláló elindulása előtt van a kapcsoló. Tehát indulás előtt lehet választani. Amikor üzemszerüen halad a mozdony a nyílt pályán, akkor a fent ismertetett időintervallumban véletlenszerủen küldi az éberségi jelzéseket. Ha 5 másodpercen belül nem érkezik nyugtázás, akkor bekapcsol a vészfék és megáll a vonat. Idő után való nyugtázással megállítható a fékezés. Ha két 
megállás között több mint 20 perc idő eltelik, akkor lehetőség van másik nyugtázási módot váltani. Erre rendelkezésre áll 5 másodperc. Ekkor külön hang és vizuális jelzés érkezik a módváltási lehetőségre.

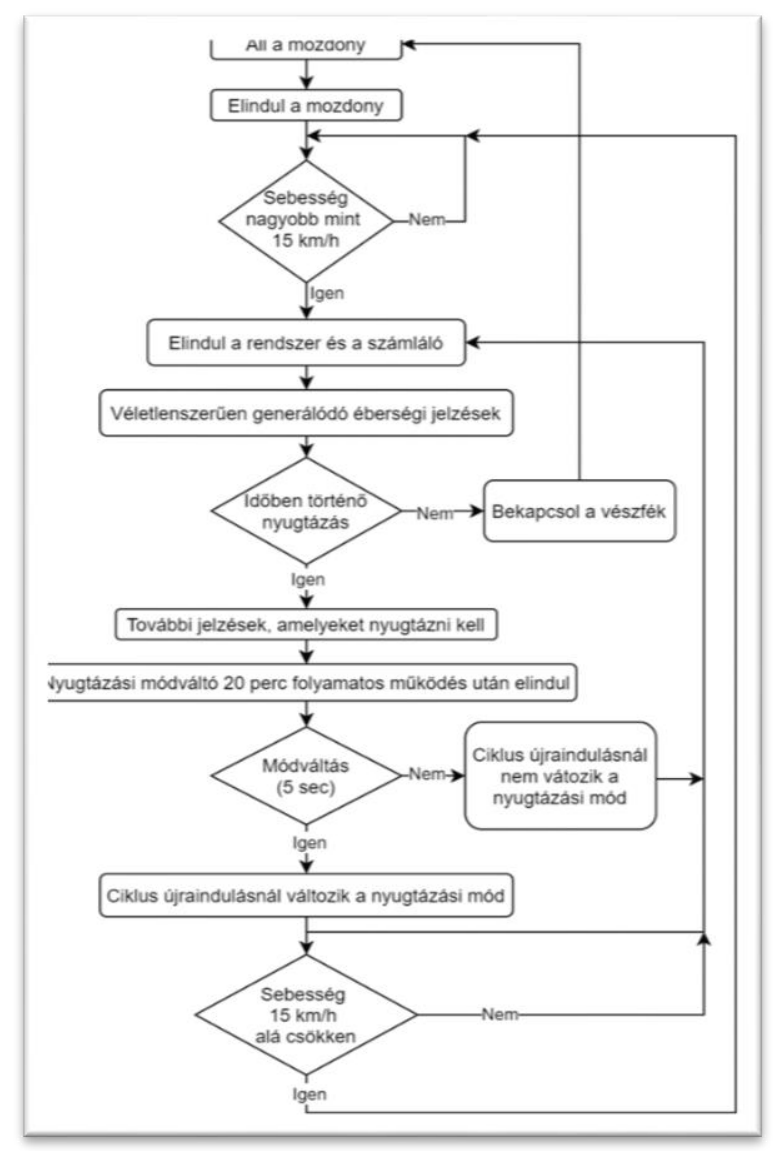

\section{4. ábra Az éberségfigyelö rendszer logikai müködésének folyamatábrája}

Ha ekkor a kétállású kapcsolóval nem vált nyugtázási módot a mozdonyvezető, akkor marad az elöző és a számláló újraindul. A változtatott módváltó csak az új 20 perces ciklussal együtt indul el. A módváltási ciklusban éberségi jelzés nem érkezik. Ez a folyamat így megy körbe mindaddig, amíg a mozdony sebessége nem csökken $15 \frac{\mathrm{km}}{\mathrm{h}}$ alá. Ezen sebesség alatt megáll a számláló így éberségi jelzések sem generálódnak.

\section{Összefoglalás}

A cikkben egy XXI. század által megkövetelt intelligenciájú vonatbefolyásolási rendszer modellje került kidolgozásra. A lefektetett rendszerhatárok között mozgó vonatbefolyásolási szint alrendszereiben számos matematikai, logikai számítás, illetve reláció került levezetésre. Számos olyan kiegészítő alrendszer integrálódik az ETCS Level 4-ben, amely a gépi döntés bevezetése után nyugodt 
szívvel kijelenthetjük, hogy megtestesíti „a félig emberi és félig automata közlekedési szintet”. Továbbá a gyakorlati megvalósítás jól reprezentálja azt, hogy ez az egyesített éberségi és vonatbefolyásolási rendszer minden eddiginél jobban törekszik a biztonságra és annak magasabb szintü biztosítására. A fékútoptimalizálás elvégzését lehetne megfogalmazni, mint további fejlesztési lehetőséget több statikus paraméter feltárásával és szükséges IoT támogatással. A kutatásban ismertetett eredmények vizuális megjelenítése egy szimulációs környezetben kézzel foghatóbban felhasználja és reprezentálja az ETCS Level 4 megálmodott rendszerét.

\section{Köszönetnyilvánítás}

A kutatási az Innovációs és Technológiai Minisztérium ÚNKP-19-2-I. kódszámú Új Nemzeti Kiválóság Programjának támogatásával készült.

\section{Irodalomjegyzék}

[1] Jóvér, B.: ETCS Az Egységes Európai Vonatbefolyásoló Rendszer, MÁV Baross Gábor Oktatási Központ 2006.

[2] Stanley, P.: ETCS for Engineers, Institution of Railway Signal Engineers 2011. (ISBN: 9783962450342)

[3] Erdei, L.: Vasúti szállítmányozás fejlesztési lehetőségeinek vizsgálata a vonatbefolyásolási rendszer fejlesztése révén, Szakdolgozat, Miskolci Egyetem, Logisztikai Intézet, 2018.

[4] Herege, J.: Vasúti berendezések müködése, MÁV Zrt. Budapest, 1973., 27/39 p.

[5] Maros, D., Tokodi, D., Tiszavölgyi, Zs.: A GSM-R rendszer jelene és jövője, Vezetékek világa 2015/1 XX. évfolyam, 1 szám. 17/21 p.

[6] Nánási, Z.: Vasúti fékezés XII. - A megfékezettség számítása, RegionalBahn, 2012. december 15.

[7] Lengyel, Gy.: Fékszámítás és vonat menetdinamikai ellenőrző program, VASÚTGÉPÉSZET, 2012. április

[8] Fehér Könyv - Útiterv az egységes európai közlekedési térség megvalósításához - Úton egy versenyképes és erőforrás-hatékony közlekedési rendszer felé, Európai Bizottság, Brüsszel, 2011, 5/19 p.

[9] Baldinia, G.: An early warning system for detecting GSM-R wireless interference in the highspeed railway infrastructure, Elsevier, Róma, 141 p.

[10] Zhang, X.; Li, J.; Liu, Y.; Zhang, Z.; Wang, Z.; Luo, D.; Zhou, X.; Zhu, M.; Salman, W.; Hu, G.; Wang, C.: Design of a Fatigue Detection System for High-Speed Trains Based on Driver Vigilance Using a Wireless Wearable EEG, Sensors 2017, 486. https://doi.org/10.3390/s17030486

[11] Nguyen, H.N., Cavalli, A.: Formal verification of coordination systems' requirements - A case study on the European Train Control System. Proceedings of the International Conference on Software Engineering and Knowledge Engineering, SEKE, pp. 393-396. (2014)

[12] Faber, J., Meyer, R.: Model checking data-dependent real-time properties of the European train control system. Proceedings of Formal Methods in Computer Aided Design, 76-77. (2006) http://doi.org/10.1109/FMCAD.2006.21 